\title{
Stand Photobooth Marvelous Century sebagai Upaya Menumbuhkan Jiwa Kewirausahaan SMK N 1 Pedan
}

\author{
Evanur Khasanah ${ }^{1)}$, Fernanda Choirul Dimassyah ${ }^{2)}$, Sri Rahayu ${ }^{3),}$ \\ 1)2)3)Universitas Muhammadiyah Surakarta \\ 1)hasannuval17@gmail.com ${ }^{2)}$ fernandadimassyah111@gmail.com \\ ${ }^{3)}$ rahayu17999@gmail.com \\ doi: 10.23917/blbs.v2i1.11607
}

\begin{abstract}
Abstrak. Sekolah Menengah Kejuruan merupakan sekolah yang mempersiapkan lulusan yang kompeten sesuai bidang keahliannya dengan meningkatkan keterampilan siswa. Perayaan Hari Ulang Tahun SMK N 1 Pedan Kabupaten Klaten yang ke-52 dengan nama Marvelous Century menjadi wadah bagi siswa untuk menyalurkan bakat dan minatnya. Seperti yang dilakukan oleh siswa kelas XII Rekayasa Perangkat Lunak SMK N 1 Pedan untuk dapat berkarya dengan menumbuhkan jiwa kewirausahaan dan kreativitasnya melalui stand photobooth. Stand Photobooth ini yang menarik minat warga sekolah untuk mendukung usaha siswa kelas XII Rekayasa Perangkat Lunak dalam menumbuhkan jiwa kewirausahaan. Adanya perkembangan teknologi salah satunya adalah berfoto untuk mengabadikan setiap momen untuk diunggah ke sosial media. Hal ini mendukung siswa kelas XII Rekayasa Perangkat Lunak untuk lebih kreatif dalam berwirausaha dengan membuka jasa foto pada stand photobooth. Tujuan artikel ini untuk menjelaskan stand photobooth Marvelous Century sebagai upaya menumbuhkan jiwa kewirausahaan siswa SMK N 1 Pedan. Penelitian ini menggunakan metode pendekatan kualitatif dengan studi kasus. Teknik pengumpulan data diperoleh melalui observasi, dokumentasi, dan wawancara. Hasil penelitian ini menunjukan bahwa stand photobooth Marvelous Century dapat meumbuhkan jiwa kewirausahaan siswa kelas XII Rekayasa Perangkat Lunak.
\end{abstract}

\section{Kata kunci: kewirausahaan, kreativitas, dan photobooth}

\section{PENDAHULUAN}

Salah satu ketrampilan yang harus dimiliki oleh siswa Sekolah Menengah Kejuruan (SMK) adalah keterampilan berwirausaha. "Keterampilan berwirausaha merupakan sebuah kemampuan yang dimiliki seseorang, sebagai bentuk penguasaan pengetahuan dan menerapkannya pada kegiatan nyata dalam kehidupan" (Saroni, 2012: 161). Sekolah Menengah Kejuruan (SMK) sebagai pendidikan menengah bertujuan agar siswanya dapat menguasai kompetensi program keahlian dan kewirausahaan untuk memenuhi tuntutan dunia kerja maupun untuk mengikuti pendidikan tinggi sesuai dengan kejuruannya (Lampiran Peraturan Menteri Pendidikan Nasional No. 23 Tahun 2006 Tentang Standar Kompetensi Lulusan). 
Perkembangan dan perubahan dunia pendidikan diindonesia tidak terlepas dari pengaruh perubahan global, perkembangan ilmu pengetahuan dan teknologi, serta seni dan budaya sudah saatnya pendidikan SMK di Indonesia harus diorientasikan untuk adaptif terhadap dinamika global dan nasional terlebih terhadap revolusi industri sekarang ini. Program pendidikan SMK dikhususkan bagi siswa yang mempunyai minat tertentu dan siap untuk bekerja serta membuka lapangan pekerjaan yang disesuiakan dengan keterampilan dan bakat yang dimiliki. Siswa SMK diajak untuk belajar disekolah dan belajar didunia kerja dengan praktek secara nyata sesuiai dengan bidang yang dipelajari.

Suryana (2014) menyatakan bahwa kewirausahaan (entrepreneurship) adalah suatu disiplin ilmu yang mempelajari tentang nilai, kemampuan (ability), dan perilaku seseorang dalam menghadapi tantangan hidup dan cara memperoleh peluang dengan berbagai risiko yang mungkin dihadapinya. Kewirausahaan merupakan suatu disiplin ilmu tersendiri, memiliki proses sistematis dan dapat diterapkan dalam bentuk penerapan kreativitas dan keinovasian. Seperti yang dilakukan siswa kelas XII Rekayasa Perangkat Lunak SMK N 1 Pedan dengan kreativitas untuk berwirausaha sesuai program keahliannya, dengan membuka stand Photobooth Marveolus Century.

Photobooth adalah sebuah area yang disediakan oleh penyelenggara acara dimana tamu dapat berpose untuk difoto dan langsung mendapatkan hasilnya saat itu juga. Membuka stand photobooth untuk merayakan hari ulang tahun sekolah dapat menambah kesan yang meriah. Stand Photobooth inilah yang digunakan sebagai alat untuk menumbuhkan jiwa kewirausahaan dalam keterampilan mendesain, mengedit dan fotografi. Usaha ini mendapat banyak respon positif seluruh warga sekolah yang dibuktikan dengan antusiasnya menggunakan jasa photobooth untuk mengabadikan momen Marvelous Century.

Dari latar belakang diatas, peneliti tergerak untuk meneliti lebih lanjut mengenai keterampilan berkewirausahaan yang diterapkan pada Stand Photobooth Marveolus Century. Permasalahan dalam penelitian ini yakni, bagaimana menumbuhkan jiwa kewirausahaan siswa, manfaat stand photobooth Marvelous Century dan bagaimana respon warga sekolah dengan adanya stand photobooth Marvelous Century. Adapun Penelitian ini bertujuan untuk mendeskripsikan stand photobooth Marvelous Century sebagai upaya menumbuhkan jiwa kewirausahaan siswa SMK N 1 Pedan. 


\section{METODE PENELITIAN}

Metode penelitian ini menggunakan pendekatan kualitatif. Menurut Saryono (2010), Penelitian kualitatif merupakan penelitian yang digunakan untuk menyelidiki, menemukan, menggambarkan, dan menjelaskan kualitas atau keistimewaan dari pengaruh sosial yang tidak dapat dijelaskan, diukur atau digambarkan melalui pendekatan kuantitatif. Jenis metode penelitian dengan pendekatan kualitatif yang digunakan adalah studi kasus untuk memperoleh data yang spesifik dan lebih intensif. Teknik pengumpulan data dalam metode ini melalui observasi, dokumentasi, dan wawancara. Instrumen penelitian adalah peneliti sendiri dan subjek penelitian adalah panitia stand photobooth kelas XII I. tempat penelitian yang dilakukan peneliti berada di SMK N 1 Pedan Klaten. Pengumpulan dan pengolahan data dilaksanakan selama 2 minggu dari tanggal 28 januari sampai 10 februari 2020 .

\section{HASIL PENELITIAN DAN PEMBAHASAN}

Berdasarkan pada penelitian yang telah dilakukan mengenai stand photobooth Marvelous Century yang bersumber dari pengamatan langsung oleh peneliti dan wawancara kepada narasumber selaku ketua panitia inti stand photobooth Kelas XII I Rekayasa Perangkat Lunak SMK N 1 Pedan. Pada perayaan HUT Kadansa ke-52 stand photobooth diadakan oleh siswa kelas XII Rekayasa Perangkat Lunak. Dengan mengikuti jejak dari kakak-kakak kelas sebelumnya yang sudah turun-temurun untuk mengadakan stand photobooth setiap perayaan HUT Kadansa. Hal ini mendorong siswa kelas XII RPL untuk membuka jasa foto pada stand photobooth untuk menyalurkan ide, kreativitas, dan menumbuhkan jiwa kewirausahaan siswa sesuai dengan bidang keahliannya. Stand photobooth ini juga ikut andil dalam memeriahkan acara HUT Kadansa ke- 52 yang bertajuk Marvelous Century.

Dalam rangka menyambut HUT Kadansa ke-52 ini siswa kelas XII RPL telah membuat perencanaan untuk mengadakan stand photobooth pada hari-hari sebelumnya dengan adanya pertemuan oleh perwakilan 3 stand untuk membahas tentang aturan stand photobooth. Stand photobooth Marvelous Century terdiri dari stand kelas XII H putri, stand kelas XII I putri, dan stand kelas XII putra jurusan Rekayasa Perangkat Lunak SMK N 1 Pedan. Pada penelitian ini peneliti mengambil sampel satu stand untuk dilakukan wawancara yaitu kelas XII I putri dengan stand photobooth yang bertema "Kekeringan" menurut peneliti menarik karena paling ramai dikunjungi dan stand photobooth 
yang elegan. "Alasan kami memilih tema ini karena menurut kami kekeringan adalah tema yang menarik dan elegan dan banyak diminati oleh generasi milenial dengan berbagai gaya dan kostum untuk foto, juga untuk mengumpulkan propertinya dianggap mudah", kata ketua panita saat diwawancarai oleh peneliti.

Stand photobooth ini memiliki anggota 35 siswi kelas XII RPL dan 14 siswi diantaranya menjadi panitia inti. Dari hasil wawancara peneliti memperoleh data anggaran yang telah dibuat oleh panitia inti. Sumber dana untuk mengadakan stand photobooth diperoleh dari swadaya anggota. Iuran sebanyak @Rp 50.000,00 sehingga diperoleh modal sebesar Rp 1.750.000,00. Alat dan bahan yang digunakan untuk stand photobooth diperoleh dengan cara menyewa. Dari modal yang telah terkumpul digunakan untuk menyewa 1 set kamera dan properti untuk dekorasi stand photobooth sesuai dengan tema yang diinginkan. Tak hanya menyewa, dari anggota juga inisiatif untuk membawa barang-barang pribadi yang dapat dijadikan sebagai properti di stand seperti kacamata, topi, dan aksesoris lainnya untuk melengkapi fasilitas pada stand photobooth yang mereka buat ketika digunakan untuk berfoto oleh warga sekolah. Daun kering yang mereka kumpulkan juga menjadi inti dari stand photobooth ini dan menjadi nilai jual yang tinggi karena sangat elegan dan cocok digunakan sebagai latar belakang foto.

Hasil yang diperoleh dari usaha membuka jasa foto pada stand photobooth selama 4 hari perayaan HUT Kadansa yang ke52 ini berbeda-beda. Pada hari pertama memperoleh pendapatan sebesar Rp 283.000,00 pada hari kedua sebesar Rp 961.000,00 kemudian pada hari ketiga sebanyak Rp 542.000,00 dan di hari terakhir sebesar $\mathrm{Rp}$ 521.000,00. Sehingga total pendapatan mencapai Rp 2.307.000,00. Pendapatan yang diperoleh dari stand photobooth sebagian dikembalikan kepada siswa untuk mengganti uang iuran, sisa yang lain digunakan untuk syukuran dengan makan -makan bersama setelah kerja keras mereka dalam berwirausaha membuka jasa foto dalam stand photobooth untuk melestarikan tradisi dari kakak-kakak kelasnya dan memeriahkan HUT Kadansa ke-52, dan ada sebagian masuk ke kas kelas.

Kendala yang dihadapi oleh panitia saat melayani foto adalah susahnya mengatur posisi pada sesi foto untuk paket foto lebih dari sepuluh orang terutama foto kelas dan foto anak ekskul yang jumlahnya banyak. Hingga membutuhkan tenaga dan pikiran yang ekstra serta kesabaran untuk mengatur posisi yang terbaik, karena pada stand photobooth mereka ingin memberikan hasil yang maksimal bagi konsumen. Tidak ada kerugian dan kerusakan selama kegiatan di stand. Namun ada barang yang 
hilang seperti kacamata yang merupakan barang pribadi bawaan anggota namun sudah diikhlaskan sehingga tidak ada ganti rugi yang dikeluarkan. Sehingga seluruh pendapatan dapat dinikmati oleh siswa kembali.

Dekorasi pada stand photobooth ini dibuat oleh siswa kelas XII I RPL baik panitia inti maupun anggota. Bekerjasama menyalurkan ide kreatif dalam mendekorasi ruang kelas yang digunakan sebagai stand photobooth dengan berbagai properti yang disewa dan dibawa oleh anggota. Selain mendekorasi sisi ruangan yang digunakan untuk photobooth panitia juga mempersiapkan hal-hal yang menunjang lancarnya usaha seperti menutup jendela dengan kertas bekas agar tidak ada cahaya yang masuk dari luar yang dapat menpengaruhi hasil tangkapan kamera. Sehingga ruang kelas yang digunakan itu sudah tampak seperti studio photo yang mewah dan memikat hati siapa saja yang melihatnya dan ingin berfoto disana. Juga mempersiapkan meja registrasi untuk melayani warga sekolah yang ingin menggunakan jasa foto pada stand photobooth.

Pengorganisasian yang baik juga menjadi salah satu faktor keberhasilan dari stand photobooth kelas XII I RPL. Kegiatan Hari Ulang Tahun Kadansa ke- 52 selama 4 hari menuntut kerja keras sesuai dengan tugas masing-masing untuk mencapai keberhasilan dari stand photobooth yang telah dibuat. Maka dari itu, panitia selalu bekerjasama dengan menjalankan tugas yang telah diamanahkan dan menjaga komunikasi yang baik agar dapat melayani konsumen dengan maksimal. Tugas-tugas yang ada selama membuka jasa foto dalam stand photobooth ada yang sebagai photografer, lighting, penata barisan, registrasi, konsumsi, properti, dan pemasaran. Jiwa kewirausahaan siswa kelas XII I RPL tumbuh dengan adanya semangat, dukungan, dan kesempatan pada momen Marvelous Century yang menjadi wadah siswa untuk berkarya dengan keterampilan dimiliki. Perayaan Hari Ulang Tahun Sekolah merupakan salah satu momen yang dinantikan oleh seluruh warga sekolah karena terdapat berbagai rangkaian acara yang menyenangkan. Pada momen ini, stand photobooth sangat efektif digunakan untuk belajar berwirausaha. Dengan mengikuti perkembangan teknologi serta memperhatikan minat konsumen, usaha jasa foto dengan membuat stand photobooth dapat menghasilkan omzet yang tinggi.

Strategi pemasaran yang dilakukan oleh kelas XII I RPL untuk menarik konsumen datang ke stand photobooth mereka untuk berfoto, mereka melakukan promosi melalui sosial media dan strategi jemput bola dengan menghampiri siswa dan guru 
untuk menawarkan jasa foto mereka juga datamg ke kelas-kelas. Mereka memasarkannya dengan membuat daftar harga yang berisi berbagai biaya untuk bermacam-macam paket foto. Sehingga konsumen dapat memilih paket mana yang dikehendaki. Dengan ini konsumen akan memperoleh hasil yang berbeda- beda sesuai paket yang dipilihnya. Dalam membuat daftar harga mereka membagi dalam dua pilihan yaitu untuk foto dengan kapasitas lebih dari 10 orang dan 10 orang. Dari tarif tersebut ada yang hanya memperoleh file saja, juga memperoleh file dan hasil cetaknya. Penentuan tarif foto ini sebelumnya sudah dikoordinasikan dengan stand yang lain agar tidak terjadi persaingan untuk menarik konsumen.

Stand photobooth ini mendapat respon positif dari warga sekolah, baik guru maupun siswa. Bahkan banyak siswa yang sengaja membawa kostum kebanggaan mereka masing-masing hanya untuk mengabadikan momen pada stand photobooth ini. Juga ibu guru yang foto dengan menaiki motor yang ada pada stand photobooth. Peneliti mengamati secara langsung bahwa terjadi antrean yang panjang karena antusias warga sekolah dalam mengabadikan momen HUT Kadansa yang ke-52 dengan stand photobooth ini. Bahkan dari mahasiswa yang sedang melaksanakan kegiatan Pengenalan Lapangan Persekolahan di SMK N 1 Pedan juga ikut menggunakan jasa foto pada stand photobooth kelas XII I RPL untuk mengabadikan momen kebersamaan dan turut serta memeriahkan HUT Kadansa ke-52 karena dinilai stand ini adalah yang terbaik dan termewah dari stand yang lain.

\section{SIMPULAN}

Berdasarkan hasil penelitian yang telah dilakukan dapat disimpulkan bahwa siswa mampu membaca peluang ketika ada event di dalam maupun luar sekolah, seperti HUT Kadansa ke52. Siswa mengetahui usaha yang sesuai bidang keahliannya dan minat dari sasaran pasarnya dengan membuka jasa foto pada stand photobooth untuk siswa dan guru SMK N 1 Pedan yang suka berfoto-foto.Dalam melayani pelanggan siswa menggunakan strategi jemput bola untuk mendapatkan pelanggan yang banyak seperti ke kelas-kelas untuk menawarkan jasa foto pada stand photoboothnya, serta menggunakan media sosial sebagai promosi. Stand photobooth ini dapat menumbuhkan jiwa kewirausahaan siswa kelas XII I RPL SMK N 1 Pedan ini ketika lulus dari sekolah bisa membuka bisnis Photobooth atau di bidang fotografi. Penelitian ini terdapat keterbatasan peneliti dalam mengumpulkan data yaitu kurangnya subjek penelitian yang menjadi narasumber. Kurangnya dokumentasi yang dilakukan peneliti selama pengamatan karena terbatasnya sarana 
prasarana yang dimiliki.

\section{DAFTAR PUSTAKA}

Ariyani, N. (2015). Jadikan Photobooth sebagai souvenir? Pertimbangkan ini. http://kompasiana.com (diakses 12 Februari 2020)

Parwatha, Pande M. (2018). SMK Sebagai Sekolah Pencetak Wirausaha Mandiri. https://baliexpress.jawapos.com (diakses 12 Februari 2020)

Peraturan Menteri Pendidikan Nasional No. 23 Tahun 2006. Tentang Standar Kompetensi Lulusan.

Saroni, M. (2012). Ketrampilan Berwirausaha. Jakarta: Ar-Ruzz

Sugiyono. (2018). Metode Penelitian Kuantitatif, Kualitatif dan R\&D. Bandung: Alfabeta

Suryana (2014) Kewirausahaan: Kiat dan Proses Menuju Sukses. Jakarta: Salemba Empat 